\title{
Exploring Self-existence through RajutKejut Craftivism: A case study in Penjaringan Forest, Jakarta
}

\author{
Sari Wulandari ${ }^{1}$, Guntur ${ }^{2}$, Martinus Dwi Marianto ${ }^{3}$ \\ ${ }^{1}$ Bina Nusantara University, Jl. KH. Syahdan No. 9, Jakarta 11480; \\ ${ }^{2}$ Institut Seni Indonesia Surakarta, Jl. Ki Hajar Dewantara No. 19, Surakarta 57126; \\ ${ }^{3}$ Institut Seni Indonesia Yogyakarta, Jl. Parangtritis KM 6,5, Yogyakarta 55188 \\ E-mail: ${ }^{1}$ swulandari@binus.edu; ${ }^{2}$ guntur@isiska.ac.id; ${ }^{3}$ mdwimarianto@gmail.com
}

\begin{abstract}
RajutKejut is a knitting community in Jakarta, Indonesia, that has been doing yarnbombing activities since 2014. In 2019, Jakarta Arts Council invited RajutKejut to collaborate with Kampung Air Baja residents in Penjaringan, North Jakarta, in a program called Young Curator Class: Titik Temu Gembira. The program combines forces between RajutKejut and urban village residents to explore life from a different perspective, specifically through art activism. This program's spirit helps residents have joyful independent lives with dignity through art that encourages life's passion. The RajutKejut Community shares its knowledge with residents on making necklaces from threads for their dance costumes. This research discusses how RajutKejut brings forward the passion of life through art activism. This research uses Alyce McGovern's Craftivism method, which dissects craftivism in personal, community, and political aspects. It shows the relation of art to the residents, how art can influence and raise an individual's potential. The community aspect shows the relation of art and the residents and how art can restore the spirit of togetherness and cooperation. On the political aspect, the art facilitates statements of empowerment from the residents. Through RajutKejut craftivism, the residents have the social capital to help them catch their breath for a while, stop their routines for a moment, and allow them to feel their existence as human beings who have expressions and feelings.
\end{abstract}

Keywords: craftivism, rajutkejut, activism, existence

\section{Eksplorasi Eksistensi Diri melalui Kraftivisme RajutKejut: Studi Kasus di Hutan Penjaringan, Jakarta ABSTRAK}

RajutKejut adalah komunitas merajut di Jakarta, Indonesia yang telah melakukan kegiatan 'bom-benang' sejak tahun 2014. Pada tahun 2019, Dewan Kesenian Jakarta mengundang RajutKejut untuk berkolaborasi dengan warga Kampung Air Baja di Penjaringan, Jakarta Utara, dalam program Kelas Kurator Muda: Titik Temu Gembira. Program tersebut menggabungkan potensi komunitas RajutKejut dan warga kampung kota untuk mengeksplorasi kehidupan melalui perspektif yang berbeda, khususnya lewat aktivisme seni. Semangat program ini adalah membantu warga untuk memiliki kehidupan mandiri yang menyenangkan dan bermartabat, melalui seni yang mendorong gairah hidup. Komunitas RajutKejut berbagi pengetahuan kepada warga kampung kota, cara membuat kalung dari benang untuk kostum tari mereka. Penelitian ini membahas bagaimana RajutKejut mendorong gairah hidup melalui aktivisme seni. Penelitian ini menggunakan metode Craftivism 
Alyce McGovern, yang membedah craftivism dalam aspek personal, komunitas, dan politik. Penelitian menunjukkan relasi seni dengan warga kampung, bagaimana seni dapat mempengaruhi dan meningkatkan potensi individu. Dalam aspek komunitas, menunjukkan bagaimana seni berelasi dengan masyarakat dapat mengembalikan semangat kebersamaan dan kerjasama. Pada aspek politik, kesenian memfasilitasi pernyataan pemberdayaan dari warga kampung. Melalui kraftivisme RajutKejut, warga kampung memiliki modal sosial untuk membantu mereka mengatur napas sejenak, menghentikan rutinitas sejenak, dan memberi mereka kesempatan untuk merasakan keberadaannya sebagai manusia yang memiliki ekspresi dan perasaan.

Kata kunci: kraftivisme, rajutkejut, aktivisme, eksistensi

\section{INTRODUCTION}

Most Jakarta people are forced to do their jobs, day in and out, with minimal time to enjoy, especially the low-income urban settlers. As a part of their job, most people in the lower economic class are constantly required to produce parts of goods, and most of the time, they cannot even afford or enjoy the finished products. They are usually alienated from the product they are producing. Most of the time, the wages' value is not comparable to the value of the goods they help to produce. This condition becomes their daily routine, without them having any power or option to get out of the circle of poverty. The situation then makes them quickly lose their existence as human beings. They are often treated more as a means of production than human beings who have extraordinary lives and feelings.

As social creatures, humans need a balance between the obligations that must be fulfilled and the rights that they deserve. One of the many aspects of life that people need is existence. However, many will feel that their existence is a luxury they cannot have due to fast and demanding routines. The condition of the low-class income earners living in Jakarta's urban villages presents the need for more and more people to get out of the crush of routines for a moment, as it is an important need to be fulfilled in order to maintain a balanced and healthy condition of mind and body.

Supported by the Jakarta Municipal Government, at the end of 2019, Jakarta Arts Council (Dewan Kesenian Jakarta - DKJ) held an art project focusing on people who live the urban villages. The project aims to help people get out of their routines, even for a moment, through art. There is a hope that by bringing back feelings, which tend to be immersed and trapped in the prevailing systems, in the form of everyday works, people will be able to regenerate their self-existence as human beings and achieve a balance of mind and body. The project believes that art can interfere with having more balanced, productive, and happy lives.

The project's focus is aimed at people who live in the urban villages in Jakarta, brought to life in the form of a village festival, and it is expected to be the medium to reach the objective. DKJ feels the need to visit the villages and invites 
the residents to have recreation through art. Getting out of their routines will create a space for them to arouse, express, and restore their existence as physically and mentally healthy human beings. DKJ, through a project called the Curatorial Work Lab (Laboratorium Kerja Kurator - LKK), a project curated by Enrico Halim, responds to the current urban villages' conditions by bringing up and doing interventions with Everyday Art, a contemporary art project that happens and exists in society's everyday life, outside the art galleries, involves people across art mediums, ages, cultures, and economic classes. As a laboratory with experimental activities, LKK does many experiments while exploring new forms to break away from the formalism of art to explore the meaning of having feelings and what it would mean to be happy. The art experiments were done by stimulating and facilitating urban village residents. They gather and express the spontaneous, rich nuances and narratives in their daily lives. Everyday art decided to call the project Happy Meeting Point (Titik Temu Gembira - TTG). The art intervention encourages and further stimulates feelings and happiness, two things that become such rare items to find in most individuals who live in Jakarta.

LKK is a participatory art practice, expects that there will be many intense interactions between artists and the urban village residents. They will do the experiments together and realize that many things may occur outside of what was originally planned. LKK has chosen activation and participation methods in an art project. These methods are expected to be able to present and refine taste sensitivity and to stimulate imagination and creativity, while at the same time bringing out the potential of the urban village residents and their environment to make not only art but also the potential to create a better life. Art is positioned as a trigger for interactions that may bring happiness as a collective work. For this reason, as an intervention program, various multi-media artists have been invited and involved in the program to stimulate and further encourage urban village residents' artistic potential.

Penjaringan City Forest Park (Taman Hutan Kota Penjaringan - THKP) has been chosen to be the site for implementing the TTG project. The park is widely used by the people from the urban middle economic class for sports and social activities, while the lower class people who live next to THKP relatively do not interact in this park. Along with the Penjaringan City Forest Park guard, located adjacent to Pluit's toll road bridge to Soekarno-Hatta International Airport, there is an urban village - a slum - located right under the bridge. The village is known as Kampung Air Baja. Some of the residents work as employees for companies that operate nearby, while others have opened small businesses in the area. By utilizing the area under the toll road bridge that can protect them from the rain, some residents also use the space as stalls for plastic bottles and cardboard collection. 


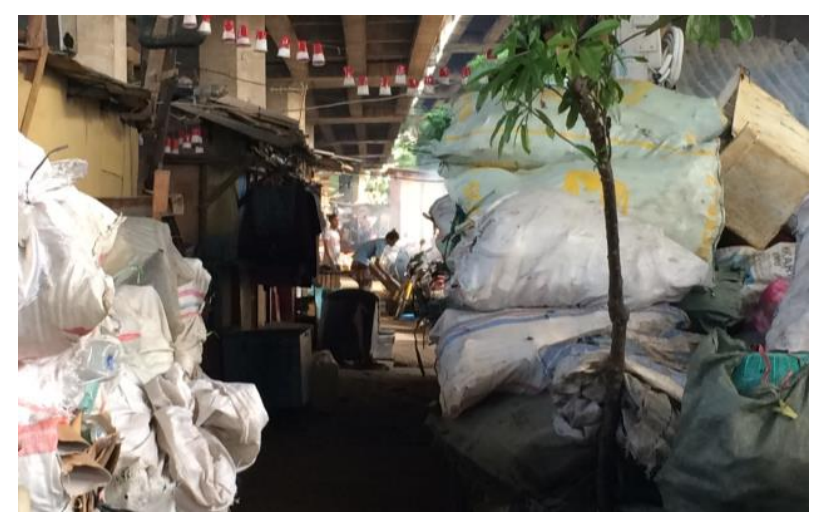

Figure 1. Kampung Air Baja Village, Penjaringan, North Jakarta. Source: Wulandari's Documentation, 2019

For the TTG project, DKJ invited RajutKejut to collaborate with the Air Baja village residents, among other artists. RajutKejut is a knitting community in Jakarta. It has been doing the yarn bombing activities since 2014. In the project, RajutKejut collaborates with the residents to explore life from a different perspective - Art Activism. The project's spirit provides residents with art, leading to joyful, happy, independent lives with dignity. Art encourages the passion of life. The program starts with RajutKejut yarnbombing the urban village and the forests located next to it with colorful knits.

RajutKejut members are surprised to see that the residents, who generally work as factory workers, domestic workers, and conventional laundry workers, have the routine of serving orders directly from employers or consumers. Their jobs need to be done, whether they like it or not. They believe that the condition can result in the loss of their self-existence that has reason and sense. As explained by Sartre, that it is not being of the existent that reveals itself (being itself is elusive), but the phenomenon of being.

"The world exists independently of consciousness due to the fact that consciousness encounters being of the existent as something accidentally (spontaneously) met, while the existent itself does not meet it at all, for its being is a constant relatedness with another existent. Selfsufficiency of the existence of the existent is emphasized by the fact that a pre-phenomenal consciousness lies beyond relations of the existent and ontologically "cannot act upon anything". ... Unlike the existent, being does not become explicit through notions and categories, but only through the description of the meaning of being of the existent that reveals itself in consciousness. A description of multiple immediate realities (man, world, relations) outlines the way to understand their underlying unity, which is being itself" (Kuzin, Makovetsky, and Drikker, 2016). 
Therefore RajutKejut tries to invite residents, especially mothers who plan to do a mass dance, to make accessories that can beautify their dance costume. They hope that through the activity of working with crafts, they can again find out how to feel and how to gather their self-existence, which will bring joy and encourage a passion for life besides broadening their knowledge of crafts. By doing works with the full awareness that the work is done for themselves, it is expected that it can encourage consciousness in mothers' minds to bring out a sense of self-existence. One of the activities that can be done is making crafts in the form of tassel necklaces. Craft, as explained by Walker, means skills, especially manual skills, to make daily necessities through thought and feelings, which usually requires a relatively long time to complete (Walker, 2010).

\section{MATERIALS AND METHOD}

The study's subject matter is residents of the urban village who make tassel necklaces for dance costume accessories. The research uses a qualitative data collection method through observations, interviews, and document reviews. The data is then analyzed by using McGovern's Craftivism method. According to Strauss and Corbin, qualitative research is a type of research whose findings are not achieved through statistical procedures or other means of manipulation but instead refer to people's lives, life experiences, behavior, emotions, and feelings, including organizational functions, movements, social, cultural phenomena, and interactions between countries. Also, Flick said qualitative research is very relevant for studying social relations, namely the plurality of the world of life. This plurality requires a new sensitivity to study empirical issues (Guntur, 2019). The term craftivism was first founded by a crafter Greer as one of 'engaged creativity, especially regarding political or social causes' (Greer, 2007). This term was then developed further by Fitzpatrick, who has expanded the definition, describes craftivism as:

"...both a strategy for non-violent activism and a mode of DIY citizenship that looks to influence positive social and political change. This uniquely 21 st Century practice involves the combination of craft techniques with elements of social and/or digital engagement as part of a proactive effort to bring attention to, or pragmatically address, issues of social, political and environmental justice" (Fitzpatrick, 2019).

In 2019, McGovern described modern craftivism as:

"...movement in more detail, and examine the practice within its broader, historical traditions. Drawing on historic and contemporary examples, the chapter documents different examples of craftivism, from war craftivism to acts of craftivism that center on social justice and gendered violence issues. As the recent revival of craftivism must be understood as part of a longer history of the intersection of craft and 
activism these examples, organized thematically, demonstrate both the continuity of craft as a protest weapon, as well as the range of issues that have been the focus of these protests across history. I summarize this overview of craftivist practices by proposing a framework I call the logics of craftivism, a Venn diagram that maps out the intersecting and interconnected personal, community, and political logics that underlie craftivist actions. The diagram also serves as a point of reference for the later analysis of yarn bombing practices, and the factors that motivate yarn bombers and frame their engagement in the act" (McGovern, 2019).

This research uses the Craftivism of McGovern's analytical method with three related aspects in Craftivism: (1) individuals, namely mothers as the tassel necklace makers; (2) the community, Kampung Air Baja; and (3) pervasive political issues. In a chart drafted by McGovern, it appears that these three are the research subjects, interconnect, and even intersect. Thus, data selection and data validation will refer to these three aspects (McGovern, 2019).

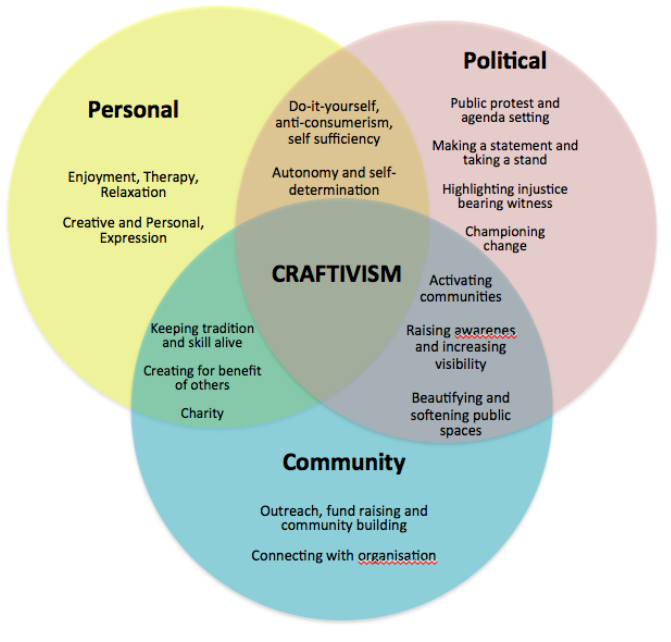

Figure 2. Craftivism Chart

Source: Craftivism and Yarn Bombing, McGovern, 2019.

The position of the researchers is as a member of RajutKejut in the TTG project. According to Pedgley, the practice-led research approach involves a researcher who carries out a design (art) project, subject to the stated objectives and research objectives. The main motive of practical- oriented researchers is to discover and communicate new knowledge and theories from their design (art) practice. It requires researchers who are skilled designers (artists) and prepared to combine the two roles of scientist and designer, something known as an intellectual challenge. Practice-led research is a research method in which design (art) practice is used to create necessary evidence against something demonstrated or discovered (Guntur, 2019). 


\section{RESULTS}

The researchers found that the value of happiness needs to be re-examined. A sense of happiness can be obtained not only through material possessions but also by non-material possessions. For example, an experience that provides a person with the opportunity to express their idea about their existence is one aspect that can make them happy. Through Craftivism's analysis, the researchers found that by making craft with complete awareness, the makers will rebuild their feelings and encourage the emergence of many individuals' potential. This could be seen in: (1) individuals, the residents who made the tassel necklaces; (2) Kampung Air Baja community; (3) pervasive political issues.

\section{DISCUSSION}

\section{Individuals, the residents who make the tassel necklaces}

The residents who tend to have minimal options in their lives and whose egos always have to be suppressed often ignore the need for recreation. To them, recreation is considered a luxury they cannot afford. Limited options happen due to limited individual abilities or limited opportunities available to residents. Thus, they often prioritize the needs over the wants, especially food and shelter, which must be fought for from day to day with minimal conditions.

Practicing arts with the residents in their everyday life residence depends on the conditions there. When a plan is going to be executed on-site, many things can happen beyond the artists' expectations. For this reason, it is essential for the artists to communicate and negotiate intensively with the residents, to explore the possible things that may exist or happen in the area, both physically and non-physically. They also need to develop empathy and be able to negotiate and compromise with residents. The things that are initially considered the ideal have to be changed or improvised because the conditions on the site are deemed inappropriate or impossible to be done in that given time. The negotiation seeks an agreeable meeting point between the conditions that are considered ideal and the reality present in the field and can be tolerated by each party.

Miscommunication and broken negotiation inevitably happen during the execution of the project. It happens among the residents, among the artists, and the residents and artists. There are a lot of potentials and energy that appear and explode together. Intensive interaction, patience, open minds, open hearts, and empathy are needed. The whole process is exhaustive, but many subtle signals that enrich insights for better communication can be picked up through it. It is not uncommon for curators and co-curators to act as mediators, motivators, and facilitators and to keep focusing on the common goal, which is happiness. To achieve this, it is 
necessary to have a more profound sense of empathy so everyone can feel the presence of joy. Things like this become a challenge when artists are faced with non-technical problems in the field.

The residents' program, especially for the mothers, starts by flash mob performed by Indonesia Dances (Indonesia Menari - IM). IM is initiated by Indonesia Kaya, an annual event sponsored by Bakti Budaya Djarum Foundation. The concept is a mass dance performance in some shopping malls. The participants will perform a mix of traditional and modern dance, following dance moves choreographed by talented Indonesian choreographers chosen for this event.

Mrs. Faidah accepts and agrees to the art experiment in the TTG project. The curator succeeds in touching Mrs. Faidah's feelings and opening her mind that results in her initiatives to hold an aerobics class for the mothers in Kampung Air Baja. Aerobic activities are close to their daily lives, but they are usually done in quite a remote location. This time, the aerobics can take place out of its territory. The aerobic activities then continue with dance practice - for the IM's flash mob event. It is Mrs. Faidah's brilliant strategy to put the dancing practice after the aerobics. It is easier to invite the mothers to practice aerobics rather than invite them to dance practice, as aerobics is easier to understand and do for them. However, it should be noted that the project's main objective is not the ability to dance well but the happy process of doing it. The process of being happy, appreciating the work of art in the form of dance, effort to be able to dance, and being excited to present their dance at the IM event, are the focus. The mothers feel the benefits of exercise and dance. Apart from being healthy, it is also a way for them to gather and meet new friends between their routines, bringing them new excitement and joy. They agree to wear a bright yellow costume with high enthusiasm, marking their identity as dancer participants.

The women of RajutKejut share their knowledge on how to make necklaces from threads, with the mothers of Kampung Air Baja, as added accessories for their dance costume. The collaborative, participatory art practice that has always been carried out by the RajutKejut community is a form of art that makes art and leaves the arts at the location and invites residents to do craftworks together. With this enthusiasm and seeing the dance participants' need to wear a costume for the event, they offer to hold training activities to help them make their tassel necklaces as their costume accessories. In this training, five RajutKejut mentors make preparations by choosing a necklace design that is easy to make but still attractive to wear as costume accessories. They also provide materials for the trainees to use. The material is made from a selection of yarns with various colors. This is to give the participants a wide range of options so they can choose their preferred color and can have the opportunity to manifest their expressions as desired. 

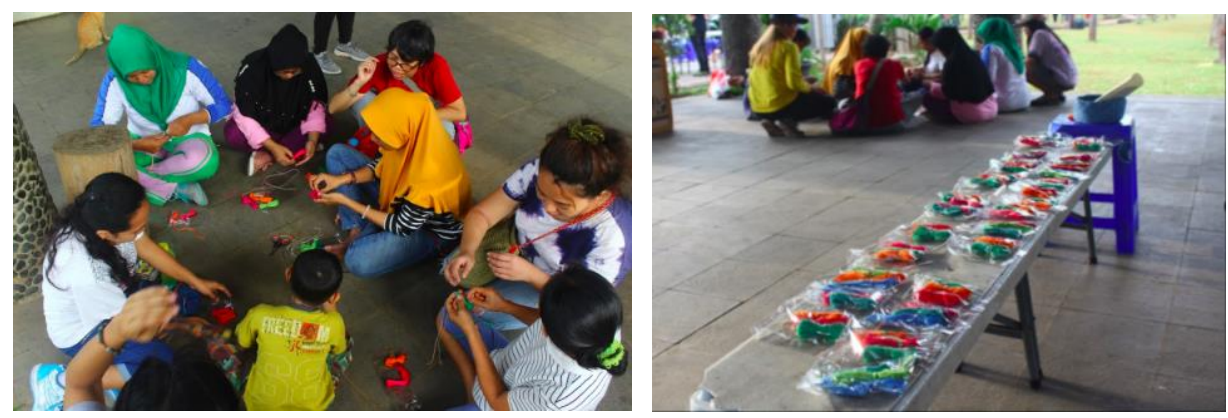

Figure 3. RajutKejut mentors with the participants. Sources: Nugroho's Documentation, 2019.

The mentors initially offer a necklace design in a photograph, with a tapestry technique in natural color shades. The participants do not seem enthusiastic about this offer because it seems complicated, and the colors in the design; examples are not attractive to them, so this model cannot be executed. The mentors then offer another example of a necklace design with a tassel technique in bright shades, worn by a woman in a contemporary style. The participants are excited because they think it is not difficult to make, and the necklace comes in vibrant colors, so it is more attractive. The right reference has an important position in making a decision. This is in line with Hume's explanation of taste, that beauty is no quality in things themselves: It exists merely in the mind that contemplates them; each mind perceives a different beauty. Beauty and worth are merely relative and consist of an agreeable sentiment, produced by an object in a particular mind, according to that mind's peculiar structure and constitution (Stradella, 2012). The participants usually spend their spare time watching soap operas on television. The consumption of drinks and snacks sold in the stalls around the residence is a daily snack for their children. All of these objects become their visual reference.

The dance instructor also has an important role to play in the decisionmaking process. The instructor, who becomes a patron for the training participants, has a "power room" to determine what a group should do. For this reason, the RajutKejut mentors negotiate with the dance instructor as she has the position as an intellectual so that the references offered could be accepted. The mentors ask for the teacher's willingness to coordinate with the dancer participants. In this case, the researchers find that hegemony is working in a system, as Gramsci explains that intellectuals perform a mediating function between class forces in the political struggle over hegemony, either as instruments of maintaining hegemony or as supporters subaltern classes promoting social change. Intellectuals fulfill their function by organizing a group's social hegemony to exert domination over the state (Bohm, 2018).

The necklace is an accessory or decoration worn on the body. It has a special 
meaning for the wearer. It is usually made of high-quality materials such as precious metals, but it is also possible that necklaces are made of natural fibers, such as fabrics and even threads. For the dance costume, necklaces are made from colorful threads. The yarn necklace training is divided into two sessions, with 20 people on each session. Each of them passes on the training to other participants. The necklace material is prepared so that the participants can immediately practice under the mentor's direction, and the tassel necklaces can be made directly at the training location. The mentors give directions for making the necklaces with standard models and simple techniques while allowing the participants to improvise necklace styles. With this creative space, the participants are excited to create their necklace models, starting from combining colors and shapes to the number of tassels used.
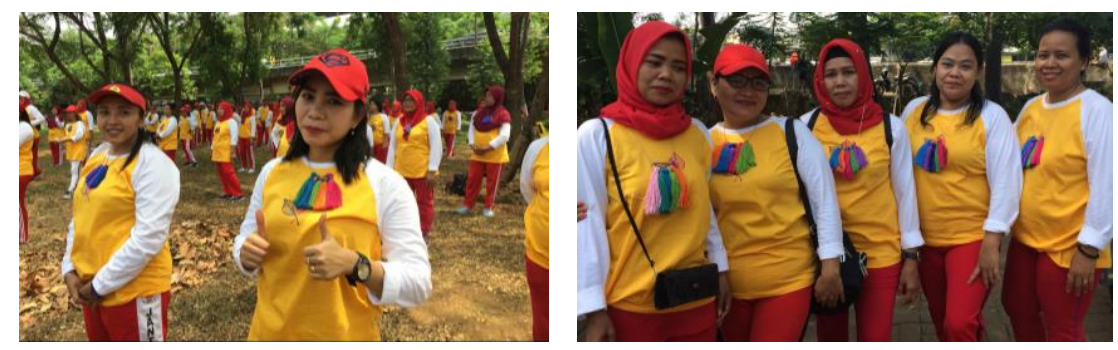

Figure 4. The participants with their own necklace models. Source: Wulandari's Documentation, 2019.

On the day, all the dance participants were ready to perform using their tassel necklaces, with various shape modifications. They discussed their work with each other and proud of their work. This condition is as explained by Boon and Pentney that craft opens up a productive space for complex and challenging conversations, in need of a process that allows actors not only to be able to listen in different ways but also to enable them to occur, learn in a different way (Boon, Sonja; Pentney, 2017). Farinosi and Fortunati elaborate more on how craft is positioned:

"...the urban knitting movement is that of handicraft. The current resurrection of knitting has grown out of the larger rediscovery of traditional handicrafts and, more generally, of DIY practices, which include not only knitting but also activities such as canning, making homemade clothes, and so forth. These practices often originate in dissatisfaction with the current economic system and represent for crafters an act of critical opposition against big corporations and mass consumer culture, as well as an autarchic desire to be self-sufficient" (Farinosi, Manuela; Fortunati, 2018).

Most people in the marginal communities of Jakarta's urban villages, who work daily as laborers and mostly struggle with earning enough money to be able to feed their families, see art activities as a luxury, but through RajutKejut, art activism, the residents have a reason to catch their breath for a while, take a pause 
from their routines, give themselves an opportunity to feel their existence as human beings who have expressions and feelings. This is in line with Mason's opinion that craft can be understood as a vehicle for activism and social change (Mason, 2019).

\section{Kampung Air Baja Community}

When seen in plain view, the conditions and the way of life of people in Kampung Air Baja are below average and even arguably not feasible (houses from plywood, not all houses have their bathroom), but they can remain happy, joyful, they can even laugh now and then, even contribute to the city while still living with dignity. Through what the mothers of Air Baja wrote in their stories and what the children draw, it appears that they have good character, and there is a potential for the residents to develop themselves more. For this reason, it needs to be sharpened and accommodated by artistic activities. A mother who has a healthy body and soul can educate her children properly. She is an important asset for community development. Moreover, experiences in childhood have a huge role in determining human character in the future.

This shared joy is manifested when around 200 women from Penjaringan dance and have fun together at the IM event at Penjaringan City Forest Park. They get together, wearing costumes written with the words "Gembira Pangkal Sehat (happiness is the foundation of a healthy life)" and the colorful tassel necklaces they make themselves. There is an interesting case where a member of the dance participants forgets her tassel necklace at home. When she realizes that she does not have enough time to get it, she expressively insists by phone that someone in her house should bring the necklace to her at the Forest Park. She must wear one and get ready to perform at the IM event. The tassel necklace is like their identity on that day. Identity, as explained by Stuart Hall:

"Since cultural diversity is, increasingly, the fate of the modern world, and ethnic absolutism a regressive feature of late-modernity, the greatest danger now arises from forms of national and cultural identity - new or old - which attempt to secure their identity by adopting closed versions of culture or community and by the refusal to engage... with the difficult problems that arise from trying to live with a difference" (Solomos, 2014).

\section{Pervasive Political Issues}

TTG has gathered many dimensions through art to create simple happiness among residents. While their day to day life forces them to go through their daily routine as workers who make products but cannot enjoy what they produce, by TTG project researchers see that they have another option to help the residents to produce something of their own that they can afford and enjoy. Through this process, it is expected that it can build people's imagination and creativity and let them see that 
happiness can be obtained in such a simple way, without losing their dignity. Along the way, this program has tickled the flexibility of artists that activism artists should be ready to face unsure conditions in the field. The artists and the collaborators will produce artworks that may be surprising and beyond the artists' expectations. This is understandable, considering among them have different preferences, values, and culture. The existence of this collaborative work requires interactions, equality in meetings, and negotiations to work on the differences. According to Piliang, work has a dialogue space where various signs, codes, and meanings come from various cultures and interact and intersect (Piliang, 2017). This is in line with Marianto's view that artworks must be viewed from two aspects: material and non-material aspects.

"Describing and analyzing are two of the various activities to observe the material aspect (the particles). In the context of semiotics, this activity is an attempt to identify, describe, and analyze in detail and overall the signifying aspects of a sign in a work of art. Observing the non-material aspect is observing the wave aspect of the artwork, identifying its meaning, message, or value through interpretation and judgment. Interpretation and judgment depend on how the work is positioned and viewed and how it is linked. Observation of material and non-material aspects is equally important, as important as the complementary relationship between particles and waves" (Marianto, 2017).

No matter how difficult life is, the residents face it with a happy heart. Many Jakarta residents should emulate this mental attitude so that they do not complain easily, work hard, are grateful that they still have a good job, and can support themselves and their families properly, in a dignified manner.

\section{CONCLUSION}

This research show many dimensions. The relation of art to the residents shows how art can influence and develop an individual's potential. This research shows how art can restore the spirit of togetherness and cooperation. On the political dimension, art facilitates statements of empowerment of the residents.

Let us look at the works of art produced by Kampung Air Baja residents in this project. We might not be impressed, and some people might even underestimate them because, in a formal aesthetic, the artworks produced do not meet the criteria as a work of art. However, if we examine the essence of art as a form of expression based on the results of thought and feelings corresponding to the environment and bringing joy, it will be legitimate if we view it as a work of art, namely the work of everyday art. Everyday works of art that can increase vitality. Halim explained Everyday Art as: 
"Everyday Art is art that is intertwined in everyday life. Everyday art is a matter of everyday human expression when acquainted with imagination and embraces it closely, without being haunted by administrative burdens shuffling around the meeting table. Art located on the outskirts and along quiet alleys is usually not considered work, other than if it has been arranged, designed, in such an exhibition format that relies on the beams of gallery lights or a book on a contemporary design cover. Art does not only belong to artists and visitors in the exclusive galleries and performances. Art is everywhere. Art that exists and lives together with everyday life" (Halim, 2019).

Evaluating the TTG project that took place during September-November 2019 by responding to THKP and the residents living in the surrounding environment, it appears that art's role in bringing a real consciousness in the residents' minds in their life. In TTG's case, happiness can be embraced by expressing and doing a simple but authentic thing. It does not only bring joy but also hope. I hope that drives the spirit to continue to navigate life with dignity.

At the end of its implementation, this interactive, experimental, and participatory LKK program produces a method that can be reused at the next everyday art project. If the urban village residents have many similar characteristics, it can be duplicated or adopted, or adapted by making various adjustments, depending on the village residents involved. Pointing to the experimental and participatory method's character, the artists who are invited need to know how to interact intensively with residents in the village environment so that the project can further encourage the emergence of works of art which have an impact on society, shared happiness which can boost a healthy and productive society.

\section{ACKNOWLEDGMENTS}

Researchers are very thankful to Jakarta Arts Council and especially to Enrico Halim as curator, for allowing and encouraging researchers to participate directly in the project.

\section{REFERENCES}

Bohm, F. (2018). Hegemony Revisited: A Conceptual Analysis of the Gramscian Concept of Hegemony in International Relations Theory. Lund University: Lund.

Boon, Sonja; Pentney, B. (2017). Knitting the Feminist Self: Craftivism, Yarn Bombing and the Navigation of Feminist Spaces. In Global Currents in Gender and Feminisms (pp. 21-34). https://doi.org/https://www.researchgate.net/deref/http\%3A\%2F\%2Fdx.doi .org\%2F10.1108\%2F978-1-78714-483-520171004

Farinosi, Manuela; Fortunati, L. (2018). Knitting Feminist Politics: Exploring a 
Yarn-Bombing Performance in a Postdisaster City. Journal of Communication Inquiry, 42(2), 138-165. https://doi.org/https://doi.org/10.1177\%2F0196859917753419

Fitzpatrick, T. (2019). Craftivism: A Manifesto/Methodology. Retrieved from Tal Fitzpatrick Blog website: https://www.talfitzpatrick.com/ craftivismmanifestomethodology

Greer, B. (2007). Craftivism: Encyclopedia of Activism and Social Justice. New York: SAGE Publications.

Guntur. (2019). A Conceptual Framework for Qualitative Research: A Literature Studies. Journal Capture, 10(2), 91-106.

Indonesia Menari. (2019). Retrieved from Indonesia Kaya website: https://www.indonesiakaya.com/indonesiamenari/2019/faq

Kuzin, I.V.; Makovetsky, E.; Drikker, A. S. (2016). Existential aspect of Being: Interpreting J. P. Sartre's Philosophy. Rupkatha Journal on Interdisciplinary Studies in Humanities, 8(1), 230-231.

Marianto, M. D. (2017). Seni dan Daya Hidup Dalam Berpikir Quantum. Yogyakarta: BP ISI Yogyakarta.

Mason, V. (2019). Craftivism. Dissident Objects and Subversive Forms. Journal of Modern Craft, 12(2), 179-183.

McGovern, A. (2019). Craftivism and Yarn Bombing: A Criminological Exploration. London: Palgrave Macmillan.

Piliang, Y. A. (2017). Hipersemiotika: Tafsir Cultural Studies Atas Matinya Makna. Yogyakarta: Jalasutra.

Solomos, J. (2014). An Appreciation - Stuart Hall: Articulations of Race, Class and Identity. Ethnic and Racial Studies, 37(10), 1667-1675.

Stradella, A. (2012). The Fiction of the Standard of Taste: David Hume on the Social Constitution of Beauty. The Journal of Aesthetic Education, 46(4), 34.

Walker, J. (2010). Desain, Sejarah, Budaya: Sebuah Pengantar Komprehensif. Yogyakarta: Jalasutra.

\section{Informan}

Enrico Halim, 51 years old. (2020). Curator for Titik Temu Gembira Jakarta Art Council, Jakarta. 